Journal of Electrical and System Control Engineering

\title{
Analisis Penurunan Cos phi dengan menentukan Kapasitas Kapasitior Bank Pada Pembangkit Tenaga Listrik Pabrik Kelapa Sawit (PKS)
}

\section{Decrease Analysis of Cos phi by determining the Capacitive Capacity of Banks in Oil Palm Pabrik Kelapa Sawit (PKS)}

\author{
Indra Roza
}

Program Studi Teknik Elektro

Universitas Harapan, Indonesia

*Coresponding author: indraroza@gmail.com

\begin{abstract}
Abstrak
Power Factor (Faktor Daya) sebagai $\cos \emptyset$, merupakan bagian yang cukup penting dalam pengoperasian suatu Generator Listrik. Karena menurunnya faktor daya ( $\cos \emptyset$ ) akan berakibat turunnya efisiensi pembangkit dalam menampung beban kerja serta akan memperbesar kemungkinan terjadinya kerusakan pada sistem pembangkit atau sistem beban listrik, sehingga perlu adanya usaha untuk memperbaiki faktor daya tersebut.Untuk kepentingan perbaikan faktor kerja, diperlukan pemasangan beberapa unit kapasitor yang dihubungkan secara paralel terhadap sistem pembangkit listrik yang kita kenal sebagai Capacitor Bank dan dilengkapi dengan Power Factor Automatic Regulator (pengatur otomatis kerja Capacitor) dan berfungsi memperbaiki faktor daya pembangkit melalui pengoperasian secara automatis unit-unit kapasitor berdasarkan besar/kecilnya beban kerja pembangkit (daya reaktif). Dari sfesifikasi Pembangkit didapat kerugian daya juga menyebabkan arus listrik (I) yang mengalir melalui kabel hantaran menjadi bertambah besar yaitu 456 A menjadi 561 A sehingga ukuran kabel yang dibutuhkan juga bertambah besar. Hal ini akan menyebabkan bertambahnya biaya investasi pemasangan jaringan kabel.Berdasarkan perhitungan kerugian akibat daya yang hilang mencapai 23\% dan kenaikan kVAR 35,71 \% sehingga hasil perhitungan kapasitas kapasitor dihubungkan bintang delta adalah 15,897 $\mu \mathrm{F}$ dan 5,292 $\mu \mathrm{F}$.Dengan adanya hasil data perbandingan factor daya normal dan turun. Memberikan masukan kepada Masyarakat dunia industry dan pabrik kelapa sawit pada system pembangkit listrik, pengendalian terjadinya kebakaran dan keselamatan manusia yang diakibatkan naiknya arus sehungga sfesifikasi kabel tidak sesuai.
\end{abstract}

Kata Kunci : Analisis, Cos $\varphi$, Kapasitas Kapasitor Bank, Pembangkit Tenaga Listrik

\begin{abstract}
Power Factor as cos $\emptyset$, is an important part in the operation of an Electric Generator. Because of the decrease in power factor ( $\cos \emptyset$ ) will result in a decrease in the efficiency of the generator in accommodating the workload and will increase the likelihood of damage to the generating system or electric load system, so that there needs to be an effort to improve the power factor. Capacitor units are connected in parallel to the power generation system that we know as Capacitor Bank and are equipped with Power Factor Automatic Regulator (automatic working capacitor Capacitor) and serves to improve the power factor of the plant through automatic operation of capacitor units based on the size of the generator work load (reactive power). From the specification of the generator obtained the power loss also causes the electric current (I) flowing through the conductive cable to become larger, namely $456 \mathrm{~A}$ to $561 \mathrm{~A}$ so that the required cable size also increases. This will lead to an increase in the investment costs of cable network installation. Based on the calculation of losses due to lost power reaches 23\% and kVAR increase by $35.71 \%$ so that the calculation of capacitor capacity connected to delta stars is $15.897 \mu \mathrm{F}$ and $5.292 \mu \mathrm{F}$. normal and down. Providing input to the world
\end{abstract}


industrial community and palm oil mills in the power generation system, controlling fire occurrence and human safety due to rising currents so that cable specifications are not suitable.

Keyword : analysis, Cos $\varphi$, Capacitor Bank Capacity, Power plant

How to Cite: Indra Roza, Analisis Penurunan Cos phi dengan menentukan Kapasitas Kapasitior Bank Pada Pembangkit Tenaga Listrik Pabrik Kelapa Sawit (PKS), 2(1) : 33-42

\section{PENDAHULUAN}

Dengan semakin tingginya tarif listrik, maka tuntutan efisiensi dalam pemakaian daya listrik adalah menjadi pertimbangan utama. Efisiensi penggunaan daya listrik dipengaruhi oleh banyak faktor. Diantaranya adalah kualitas daya listrik. Kualitas daya listrik sangat dipengaruhi oleh penggunaan jenis-jenis beban tertentu yang mengakibatkan turunnya efisiensi. Jenisjenis beban yang mempengaruhi kualitas daya listrik adalah beban-beban induktif, seperti; motor induksi, kumparan, ballast, lampu TL. Demikian juga beban-beban non linier seperti; konverter dan inverter untuk drive motor, mesin las, furnace, komputer, ac, tv, lampu TL dan lain-lain. Baban-beban induktif akan menurunkan faktor daya sehingga dapat menyebabkan denda apabila faktor daya kurang dari 0.85 lag, sedangkan beban-beban non linier tersebut menimbulkan harmonisa yang dampaknya akan mempengaruhi kualitas daya, sehingga menimbulkan kerugian - kerugian.

Sedangkan gangguan lain adalah gangguan yang disebabkan karena adanya fluktuasi pemakaian beban, terutama untuk beban-beban yang bersifat on/off seperti crane, furnace, pompa, welding dll.

Kerusakan pada prime mover generator, terutama Diesel genset dengan pembebanan sampai $80 \%$, sehingga pada akhirnya akan memperpendek usia pemakaian, seringnya maintenance dan akan memakan biaya pemeliharaan yang cukup besar. Untuk mendapatkan kualitas tenaga listrik yang baik, maka perlu dilakukan langkah-langkah perbaikan kualitas daya.

Berdasarkan perhitungan kerugian akibat daya yang hilang mencapai 23\% sehingga . Jadi jelas bahwa penurunan faktor daya generator dari 0,85 menjadi 0,6 akan berakibat terjadinya pemborosan biaya pemakaian. Dengan adanya hasil data melalui perbandingan factor daya norlma dan turun. Memberikan masukan kepada Masyarakat dunia industry dan pabrik kelapa sawit pada pembangki untuk memasang kapasitor bank sehingga daya yang hilang tidak terlalu besar dan, pengendalian terjadinya kebakaran dan keselamatan manusia yang diakibatkan tidak sesuai sfesifikasi kabel yang diakibat arus naik. Perhitungan kapasitro Bank akan memberikan kontribusi terhadap pengembangan ilmu dan teknologi di lingkungan akademik.

\section{Daya}

Daya adalah energi yang dikeluarkan untuk melakukan usaha. Dalam sistem tenaga listrik, daya merupakan jumlah energi yang digunakan untuk melakukan kerja atau usaha. Daya listrik biasanya dinyatakan dalam satuan Watt atau Horsepower (HP),Horsepower merupakan satuan daya listrik dimana $1 \mathrm{HP}$ setara 746 Watt atau lbft/second. Sedangkan Watt merupakan unit daya listrik dimana 1 Watt memiliki daya setara dengan daya yang dihasilkan oleh perkalian arus 1. 


\section{Daya Aktif}

Daya aktif (Active Power) adalah daya yang terpakai untuk melakukan energi sebenarnya. Satuan daya aktif adalah Watt. Misalnya energi panas, cahaya, mekanik dan lain - lain.

$$
\begin{aligned}
& \mathrm{P}=\mathrm{V} . \mathrm{I} \operatorname{Cos} \varphi \\
& \mathrm{P}=\sqrt{3} \cdot \mathrm{V}_{\mathrm{L}} \cdot \mathrm{I}_{\mathrm{L}} \operatorname{Cos} \varphi
\end{aligned}
$$

Daya ini digunakan secara umum oleh konsumen dan dikonversikan dalam bentuk kerja.

\section{Daya Reaktif}

Daya reaktif adalah jumlah daya yang diperlukan untuk pembentukan medan magnet. Dari pembentukan medan magnet maka akan terbentuk fluks medan magnet. Contoh daya yang menimbulkan daya reaktif adalah transformator, motor, lampu pijar dan lain - lain. Satuan daya reaktif adalah

$$
\begin{aligned}
& Q=V . I \operatorname{Sin} \varphi \\
& Q=\sqrt{3} \cdot V_{L} \cdot I_{L} \operatorname{Sin} \varphi
\end{aligned}
$$

\section{Daya Nyata}

Daya nyata (Apparent Power) adalah daya yang dihasilkan oleh perkalian antara tegangan rms dan arus rms dalam suatu jaringan atau daya yang merupakan hasil penjumlahan trigonometri daya aktif dan daya reaktif. Satuan daya nyata adalah VA.

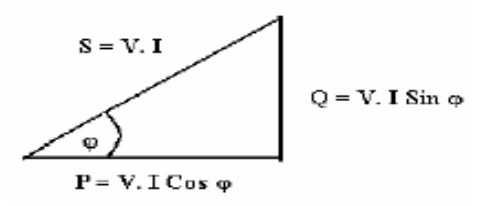

Gambar. 1 Penjumlahan trigonometri daya aktif, reaktif dan daya nyata

$\mathrm{S}=\mathrm{P}+\mathrm{jQ}$, mempunyai nilai/ besar dan sudut .

$\mathrm{S}=\mathrm{S} \angle \varphi$

$\mathrm{S}=\sqrt{\mathrm{P}^{2}}+\sqrt{\mathrm{Q}^{2}}<\varphi$
Untuk mendapatkan daya satu phasa, maka dapat diturunkan persamaannya :

$$
\begin{aligned}
& \mathrm{S}=\mathrm{P}+\mathrm{jQ} \\
& \mathrm{P}=\mathrm{V} . \mathrm{I} \operatorname{Cos} \varphi \\
& \mathrm{Q}=\mathrm{V} . \mathrm{I} \operatorname{Sin} \varphi \\
& \text { maka }: \\
& \mathrm{S} 1 \varphi=\mathrm{V} . \mathrm{I} . \operatorname{Cos} \varphi+\mathrm{j} \text { V. I Sin } \varphi \\
& \mathrm{S} 1 \varphi=\text { V. I. }(\operatorname{Cos} \varphi+\mathrm{j} \operatorname{Sin} \varphi) \\
& \mathrm{S} 1 \varphi=\mathrm{V} . \mathrm{I} . e \mathrm{j} \varphi \\
& \mathrm{S} 1 \varphi=\mathrm{V} . \mathrm{I} \angle \varphi \\
& \mathrm{S} 1 \varphi=\mathrm{V} . \mathrm{I}^{*}
\end{aligned}
$$

Sedangkan untuk rangkaian tiga phasa mempunyai 2 bentuk hubungan yaitu :Hubungan Wye (Y)

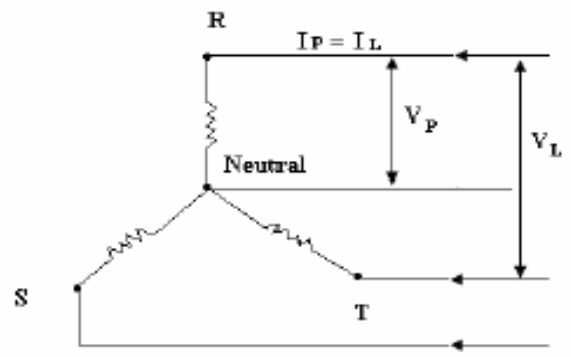

$$
\text { Gambar } 2 \text { Hubungan Bintang }
$$

Dimana :

VRS $=$ VRT $=$ VST $=$ VL $;$ Tegangan antar phasa $\mathrm{VRN}=\mathrm{VSN}=\mathrm{VTN}=\mathrm{VP} ;$ Tegangan phasa IR = IS = IT = IL (IP) ; Arus phasa /Arus saluran

Bila IL adalah arus saluran dan IP adalah arus phasa, maka akan berlaku hubungan:

$$
\begin{aligned}
\mathrm{IL} & =\mathrm{IP} \\
\mathrm{VL} & =3 \mathrm{VP}
\end{aligned}
$$

Hubungan Delta $(\Delta)$ 


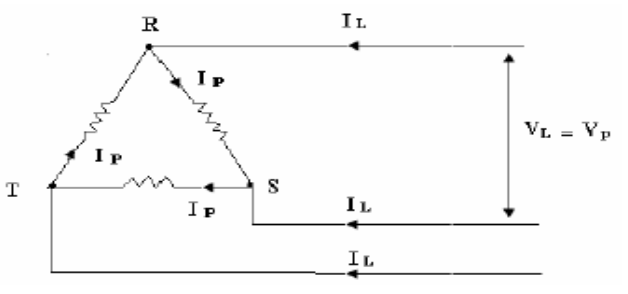

Gambar 3 Hubungan Delta

Dari kedua jenis rangkaian di atas, untuk mendapatkan daya tiga phasanya maka:

$$
S(3)=3 . \text { VL. IL }
$$

\section{Faktor Daya}

Faktor daya (Cos $\varphi)$ dapat didefinisikan sebagai rasio perbandingan antara daya aktif (Watt) dan daya nyata (VA) yang digunakan dalam sirkuit AC atau beda sudut fasa antara $\mathrm{V}$ dan I yang biasanya dinyatakan dalam $\cos \varphi$.

$$
\begin{aligned}
\text { Faktor Daya } & =\text { Daya Aktif (P) / Daya Nyata (S) } \\
& =\mathrm{kW} / \mathrm{kVA} \\
& =\mathrm{V} . \mathrm{I} \operatorname{Cos} \varphi / \text { V.I } \\
& =\operatorname{Cos} \varphi
\end{aligned}
$$

Faktor daya mempunyai nilai range antara 0 - 1 dan dapat juga dinyatakan dalam persen. Faktor daya yang bagus apabila bernilai mendekati satu.

$$
\begin{aligned}
\operatorname{Tan} \varphi & =\text { Daya Reaktif }(\mathrm{Q}) / \text { Daya Aktif }(\mathrm{P}) \\
& =\text { Kvar } / \mathrm{kW}
\end{aligned}
$$

karena komponen daya aktif umumnya konstan (komponen kVA dan kVAR berubah sesuai dengan faktor daya), maka dapat ditulis seperti berikut :

Daya Reaktif (Q) = Daya Aktif (P) $\times \operatorname{Tan} \varphi$ sebuah contoh, rating kapasitor yang dibutuhkan untuk memperbaiki faktor Daya sebagai berikut :

Daya reaktif pada $p f$ awal $=$ Daya Aktif $(\mathrm{P})$ $\mathrm{x} \operatorname{Tan} \varphi 1$

Daya reaktif pada $p f$ diperbaiki = Daya Aktif (P) x Tan $\varphi 2$

Sehingga rating kapasitor yang diperlukan untuk memperbaiki faktor daya adalah :

Daya reaktif $(\mathrm{kVAR})=$ Daya Aktif $(\mathrm{kW}) \mathrm{x}$ $(\operatorname{Tan} \varphi 1-\operatorname{Tan} \varphi 2)$

Beberapa keuntungan meningkatkan faktor daya :

1. Tagihan listrik akan menjadi kecil (PLN akan memberikan denda jika $p f$ lebih kecil dari 0,85)

2. Kapasitas distribusi sistem tenaga listrik akan meningkat

3. Mengurangi rugi - rugi daya pada system

4. Adanya peningkatan tegangan karena daya meningkat.

Jika $p f$ lebih kecil dari 0,85 maka kapasitas daya aktif (kW) yang digunakan akan berkurang. Kapasitas itu akan terus menurun seiring dengan menurunnya $p f$ sistem kelistrikan. Akibat menurunnya $p f$ maka akan timbul beberapa persoalan diantaranya :

Kelebihan pemakaian kVARH $=[\mathrm{B}-0,62($ $\mathrm{A} 1+\mathrm{A} 2 \mathrm{~J}] \mathrm{Hk}$

Dimana :

$\mathrm{B}$ = pemakaian $\mathrm{kVARH}$

$\mathrm{A} 1$ = pemakaian $\mathrm{kWH}$ WPB 
A2 = pemakaian kWH LWBP

$\mathrm{Hk}=$ harga kelebihan pemakaian $\mathrm{kVARH}$

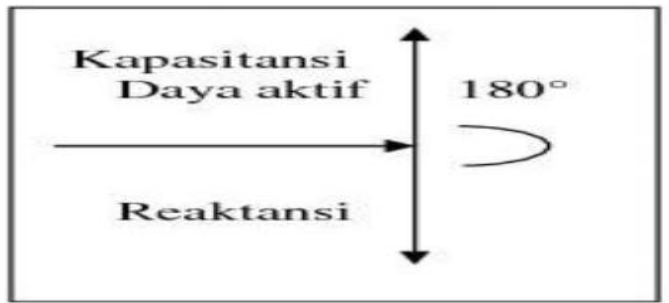

Gambar 4. Hubungan daya reaktif, reaktif dan kapasitansi

Seperti terlihat pada gambar 4, daya reaktif yang dibutuhkan oleh induktansi selalu mempunyai beda fasa $90^{\circ}$ dengan daya aktif. Kapasitor menyuplai kVAR dan melepaskan energi reaktif yang dibutuhkan oleh induktor. Ini menunjukan induktansi dan kapasitansi mempunyai beda fasa.

Beberapa strategi untuk koreksi faktor daya adalah :

1. Meminimalkan operasi dari beban motor yang ringan atau tidak bekerja

2. Menghindari operasi dari peralatan listrik diatas tegangan rata - ratanya

3. Mengganti motor - motor yang sudah tua dengan energi efisien motor. Meskipun dengan energi efisien motor, bagaimanapun faktor daya diperngaruhi oleh beban yang variasi. Motor ini harus dioperasikan sesuai dengan kapasitas rat - ratanya untuk memperoleh faktor daya tinggi.

4. Memasang kapasitor pada jaringan AC untuk menurunkan medan dari daya reaktif.

Selain itu, pemasangan kapasitor dapat menghindari :

1. Trafo kelebihan beban (overload), sehingga memberikan tambahan daya yang tersedia

2. Voltage drops pada line ends
3. Kenaikan arus / suhu pada kabel, sehingga mengurangi rugi - rugi.

Untuk pemasangan Capasitor Bank diperlukan :

1. Kapasitor, dengan jenis yang cocok dengan kondisi jaringan

2. Regulator, dengan pengaturan daya tumpuk kapasitor (Capasitor Bank) otomatis

3. Kontaktor, untuk switching kapasitor

4. Pemutus tenaga, untuk proteksi tumpuk kapasitor.

Resistansi Kawat Penghantar

Tiap-tiap logam mempunyai tahanan jenis ( $\rho$ ) yang tertentu besarnya. Makin kecil nilai tahanan jenis (resistivity) suatulogam makin baik digunakan sebagai kawat penghantar. Sepertihalnya kawat tembaga mempunyai tahanan jenis yang palingrendah $(0,0175)$ merupakan logam yang sangat baik digunakansebagai kawat penghantar dibandingkan dengan kawataluminium yang mempunyai tahanan jenis 0,030.

Tahanan jenis inilah yang merupakan salah satu faktor untukmenentukan besarnya tahanan (resistance) $\mathrm{R}$ dalam suatu kawatpenghantar, disamping faktor-faktor luas penampang kawat (A)dan panjang kawat (l) pada suatu penghantar jaringan. Dimanabesarnya tahanan dari suatu kawat penghantar sebanding denganpanjangnya dan berbanding terbalik dengan luas penampangkawat, yang dinyatakan dengan persamaan :

$$
R=\rho \frac{l}{A}
$$

Dimana :

$\mathrm{R}$ = besarnya tahanan kawat $(\Omega)$

$\rho=$ nilai tahanan jenis kawat $(\mathrm{m} / \mathrm{mm})$ 
$\mathrm{l}=$ panjang kawat penghantar $(\mathrm{m})$

$\mathrm{A}=$ luas penampang kawat $(\mathrm{mm} 2)$

Makin panjang suatu jaringan makin jauh pula jarak tempuh arus listrik dan makin besar tahanan kawat tersebut. Sebaliknya kalau diameter kawat makin besar, maka aliran listrik dapat mengalir dengan mudah dan nilai tahanan makin kecil. Begitu pula makin besar diameter kawat makin lebar ukuran beban pelayanan yang harus dilayani.

Selain dari pada itu besarnya tahanan suatu kawat penghantar akan berubah karena pengaruh suhu. Makin besar perbedaan kenaikan suhu makin bertambah besar tahanan kawat penghantar. Perubahan besarnya nilai tahanan tersebut sesuai

dengan persamaan :

$R t=R t o\{1+\alpha(t-t o)\}$

Dimana :

$\mathrm{Rt}$ = besarnya tahanan pada kenaikan suhu t C $(\Omega)$

Rto = besarnya tahanan pada suhu semula $(\Omega)$

$\mathrm{t}=$ suhu sekarang $\left({ }^{\circ} \mathrm{C}\right)$

to $=$ suhu mula-mula $\left({ }^{\circ} \mathrm{C}\right)$

á = koefisien suhu

Konduktivitas Kawat Penghantar

Nilai konduktivitas suatu kawat penghantar dinyatakan sebagai perbandingan terbalik dengan besarnya tahanan, yang besarnya dinyatakan dengan persamaan :

$$
C=\frac{1}{R}
$$

Dimana :
$\mathrm{C}=$ besarnya konduktivitas kawat penghantar (mho)

Berarti makin besar suatu tahanan kawat penghantar makin kecil nilai konduktivitasnya. Konduktivitas suatu kawat penghantar ini tergantung pula pada kemurnian dari logam yang digunakan, akan makin besar bila kemurnian logam bertambah tinggi dan berkurang bila campurannya bertambah. Karena faktor-faktor tersebut diatas maka besarnya konduktivitas tidak bisa mencapai nilai tepat $100 \%$. Bila digunakan aluminium yang sebelumnya mempunyai konduktivitas rendah dari tembaga, nilainya tidak akan berkurang dari $60 \%$.

\section{METODE PENELITIAN}

Waktu dan Tempat Pelaksanaan

Pelaksanaan rancang bangun ini direncanakan akan dilaksankan selama 4 (empat) bulan. Dengan lokasi rancang bangun alat tersebut di Laboratorium Jurusan Teknik Elektro Universitas Harapan Medan.

\section{Teknis Analisis Data}

Teknik pengumpulan data yang dilakukan untuk memperoleh data primer berupa daya aktif, daya reaktif, dan daya nyata serta data sekunder berupa Nameplate sebuah generator Diesel di industri menggunakan teknik observasi. selanjutnya, setelah capacitor bank terpasang, diperoleh dengan mengadakan pengukuran terhadap daya dan faktor daya. Data yang dianalisis berupa data daya aktif, daya reaktif, daya semu, dan nominal tagihan listrik berupa denda $\mathrm{kVAr}$ yang harus dibayar. Analisis data 
dilakukan dengan melakukan perhitungan terhadap kerugian elektris dan kerugian ekonomis setelah digunakannya capacitor bank.

\section{Hasil dan Pembahasan}

\section{Perhitungan Faktor Daya}

Berikut ini adalah data-data sebuah Generator Diesel

$\begin{array}{ll}\text { Kapasitas Daya (W) } & =300 \mathrm{KVA} \\ \text { Tegangan Kerja }\left(\mathrm{V}_{3 \varnothing}\right) & =380 \mathrm{Volt} \\ \text { Frekwensi (f) } & =50 \mathrm{~Hz} \\ \text { Faktor Daya Pembangkit } & =0.8 \\ \text { Arus (I) } & =456 \mathrm{Ampere} \\ \text { Daya Effektif (P) } & =240 \mathrm{KW}\end{array}$

Dari data-data Generator di atas, dapat diartikan bahwa Generator Listrik tersebut dapat bekerja optimal jika semua persyaratan parameter kerjanya terpenuhi. Untuk mendapatkan gambaran secara jelas dari pengaruh turunnya Faktor Daya Generator (Cos Ø) dapat dilihat dari perhitungan berikut :

Faktor Daya Generator turun dari 0,8 menjadi 0,65

$\mathrm{C}=$ Daya Reaktif (loss power) dalam satuan KVA

$\mathrm{I}=$ Arus listrik dalam satuan Ampere

$$
\begin{aligned}
& \text { Maka : } \mathrm{P}=\sqrt{3} \times \mathrm{V} \times \mathrm{I} \times \operatorname{Cos} \emptyset \quad(\mathrm{KW}) \\
& \mathrm{P}=\mathrm{W} \times \operatorname{Cos} \varnothing \quad(\mathrm{KW}) \\
& C=\sqrt{ }\left(W^{2}-P^{2}\right) \quad \text { (KVAR) }
\end{aligned}
$$

Dari Formulasi (1) dapat dihitung : Besarnya Arus Listrik (I) yang mengalir untuk kedua kondisi Faktor Daya Generator, sebagai berikut :

\section{$\underline{\text { Untuk } \operatorname{Cos} \emptyset=0,8}$}

Maka :

$$
\begin{aligned}
P & =\sqrt{3} \times \mathrm{V} \times \mathrm{I} \times \operatorname{Cos} \emptyset \\
240.000 & =1,732 \times 380 \times \mathrm{I} \times 0,8 \\
\mathrm{I} & =240.000 /(1,732 \times 380 \times 0,8) \\
\mathrm{I} & =456 \text { Ampere }
\end{aligned}
$$

$\underline{\text { Untuk } \operatorname{Cos} \emptyset=0,65}$
Maka :

$$
\begin{aligned}
\mathrm{P} & =\sqrt{3} \times \mathrm{V} \times \mathrm{I} \times \operatorname{Cos} \emptyset \\
240.000 & =1,732 \times 380 \times \mathrm{I} \times 0,65 \\
\mathrm{I} & =240.000 /(1,732 \times 380 \times 0,65) \\
\mathrm{I} & =561 \text { Ampere }
\end{aligned}
$$

Dari Formulasi (2) dapat dihitung :

Besarnya Resultan Daya (Daya Total $=\mathrm{W}$ ), sebagai berikut :

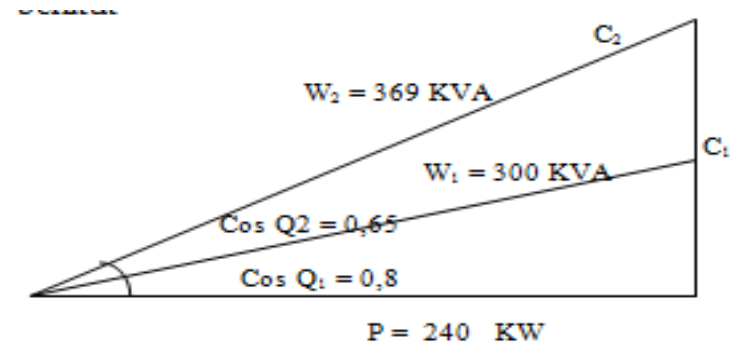

Gambar. 5. Besar Resultan Daya total

Untuk $\operatorname{Cos} \emptyset=0,8$

$$
\text { Maka : } \begin{aligned}
\mathrm{P} & =\mathrm{W} \times \operatorname{Cos} \emptyset \\
240 & =\mathrm{W} \times 0,8 \\
\mathrm{~W} & =300 \mathrm{KVA}
\end{aligned}
$$

Untuk $\operatorname{Cos} \emptyset=0,65$

$$
\text { Maka : } \quad \begin{array}{r}
\mathrm{P}=\mathrm{W} \times \operatorname{Cos} \varnothing \\
240=\mathrm{W} \times 0,65 \\
\mathrm{~W}=369 \mathrm{KVA}
\end{array}
$$

Dari Formulasi (3) dapat dihitung :

Besarnya daya Reaktif C (kVAR), sebagai berikut :

Untuk $\operatorname{Cos} \emptyset=0,8$

$$
\text { Maka : } \quad \begin{aligned}
C & =\sqrt{(}\left(\mathrm{W}^{2}-\mathrm{P}^{2}\right) \\
C & =\sqrt{ }\left(300^{2}-240^{2}\right) \\
\mathrm{C} & =\sqrt{32.400} \\
\mathrm{C} & =180 \mathrm{KVAR}
\end{aligned}
$$

Untuk $\operatorname{Cos} \emptyset=0,65$

$$
\text { Maka : } \quad \begin{aligned}
C & =\sqrt{ }\left(\mathrm{W}^{2}-\mathrm{P}^{2}\right) \\
\mathrm{C} & =\sqrt{ }\left(369^{2}-240^{2}\right) \\
\mathrm{C} & =\sqrt{78.561} \\
\mathrm{C} & =280 \mathrm{KVAR}
\end{aligned}
$$

Berdasarkan Formulasi diatas dapat diketahui besarnya :

Arus yang hilang :

I Loss $=\mathrm{I}_{2}-\mathrm{I}_{1}$ 
I Loss $=561$ Amp -456 Amp

I Loss $=105$ Ampere

Maka

$\mathrm{I}$ Loss $=(561-456 / 456) \times 100=23 \%$

Tabel $1 \operatorname{Cos} \emptyset=0,8$ dan 0,65 terhadap arus (I)

\begin{tabular}{|c|c|c|c|}
\hline $\begin{array}{c}\text { Besar Cos } \\
\varnothing\end{array}$ & Arus ( $\left.\mathbf{I}_{\mathbf{1}}\right)$ & Arus ( $\left.\mathbf{I}_{\mathbf{2}}\right)$ & Daya Hilang \\
\hline 0,8 & $456 \mathrm{~A}$ & - & \multirow{2}{*}{$105 \mathrm{~A}$} \\
\hline 0,65 & - & 561 & \\
\hline
\end{tabular}

Dari table diatas menjelaskan adanya perbedaan arus yang signifikan dari perbedaana $\cos \varnothing$ sehingga dapat kita simpulkan bahwa adanya kehilangan arus yang akan mengakibatkan penurunan daya, sementara daya sangat diperlukan .

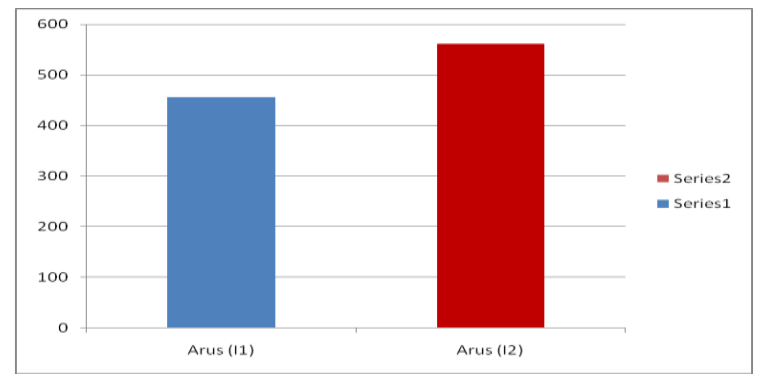

Gambar 6 ._Grafik $\operatorname{Cos} \varnothing=0,8$ dan 0,65 terhadap arus (I)

Daya yang hilang :

$$
\begin{aligned}
& \mathrm{W} \text { Loss }=\mathrm{W}_{2}-\mathrm{W}_{1} \\
& \mathrm{~W} \text { Loss }=369 \mathrm{KVA}-300 \mathrm{KVA} \\
& \mathrm{W} \text { Loss }=69 \mathrm{KVA}
\end{aligned}
$$

Maka :

$\mathrm{W}$ Loss $=369-300 / 300 \times 100=23 \%$ Kenaikan Daya Reaktif :

$$
\begin{aligned}
\mathrm{C}= & \mathrm{C}_{2}-\mathrm{C}_{1} \\
\mathrm{C}= & 280 \mathrm{KVAR}-180 \mathrm{KVAR} \\
\mathrm{C}= & 100 \mathrm{KVAR} \text { atau } \\
& \text { kenaikan } \mathrm{C}=35,71 \%
\end{aligned}
$$

Tabel $2 \operatorname{Cos} \emptyset=0,8$ dan 0,65 terhadap daya yang

\begin{tabular}{|c|c|c|c|c|}
\hline $\begin{array}{c}\text { Besar } \\
\text { Cos } \varnothing\end{array}$ & $\begin{array}{c}\text { Daya } \\
\text { Aktif }\end{array}$ & $\begin{array}{c}\text { Daya } \\
\text { Nyata }\end{array}$ & $\begin{array}{c}\text { Daya } \\
\text { Reaktif }\end{array}$ & $\begin{array}{c}\text { Daya } \\
\text { Hilang }\end{array}$ \\
\hline 0,8 & $240 \mathrm{KW}$ & $300 \mathrm{KVA}$ & $180 \mathrm{KVAR}$ & \multirow{2}{*}{$69 \mathrm{KVA}$} \\
\cline { 1 - 1 } 0,65 & $240 \mathrm{KW}$ & $369 \mathrm{KVA}$ & $280 \mathrm{KVAR}$ & \\
\hline
\end{tabular}

Dari table diatas menjelaskan adanya perbedaan daya nyata dan daya reaktif sedangkan daya aktif nya tetap akibat adanya perbedaana cos $\emptyset$ sehingga dapat kita simpulkan bahwa adanya kehilangan daya nyata dan meningkat daya reaktif diakibat turunnnya $\operatorname{Cos} \varnothing$ yang akan mengakibatkan kehilangan daya nyata.

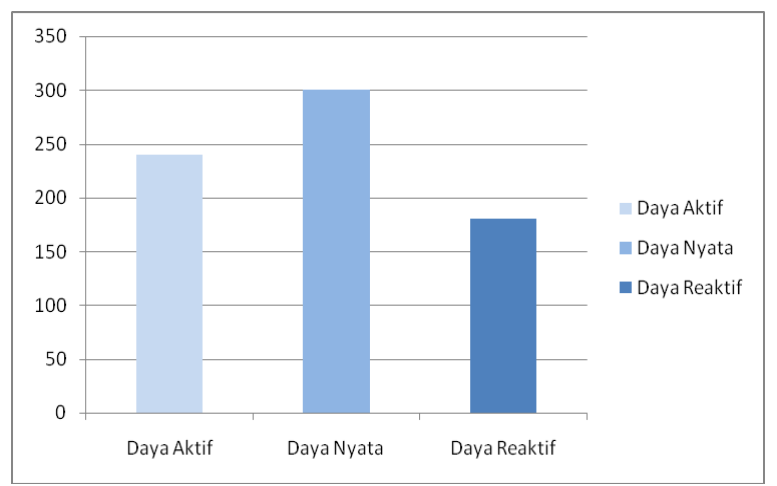

Gambar 7 Grafik segitiga Daya untuk Cos $\emptyset=0,8$

Dari grafik diatas terlihat adanya besar daya yang digunakan baik itu daya aktif, daya nyata dan daya reaktif dengan $\operatorname{Cos} \emptyset=0,8$

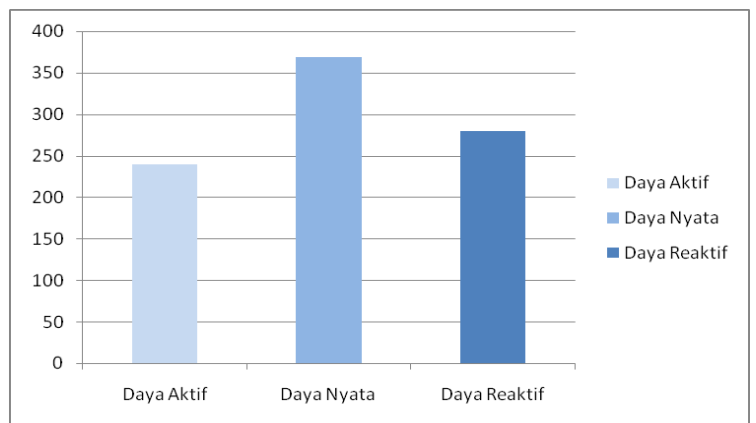

Gambar 8 Grafik segitiga Daya untuk Cos $\emptyset=0,65$

Dari gambar. 7 dan 8 diatas terlihat adanya perubahan daya nyata agak lebih besar dibandingkan dcengan gambar 5.3 begitu juga daya reaktif semakin besar diakibatkan penurunan $\operatorname{Cos} \varnothing=0,65$, sedangkan daya aktif nyata tetap. 
Tabel 3 Kondisi sebelum dan sesudah kompensasi

\begin{tabular}{|c|c|c|c|c|c|}
\hline \multirow{2}{*}{ Kondisi } & \multicolumn{5}{|c|}{} \\
\cline { 2 - 6 } & $\begin{array}{c}\text { Arus } \\
\text { (A) }\end{array}$ & $\operatorname{Cos} \varnothing$ & P (Watt) & Q (VAR) & S (VA) \\
\hline $\begin{array}{c}\text { Sebelum } \\
\text { Kompensasi }\end{array}$ & 456 & 0.65 & $240 \mathrm{~K}$ & $280 \mathrm{~K}$ & $369 \mathrm{~K}$ \\
\hline $\begin{array}{c}\text { Sesudah } \\
\text { Kompensasi }\end{array}$ & 561 & 0.80 & $240 \mathrm{~K}$ & $180 \mathrm{~K}$ & $300 \mathrm{~K}$ \\
\hline Selisih & 105 & 0.15 & 0 & $100 \mathrm{~K}$ & $69 \mathrm{~K}$ \\
\hline
\end{tabular}

Dari perhitungan perhitungan diatas, dapat dilihat timbulnya Power Loss (keborosan Daya) yang diakibatkan turunnya Faktor Daya Generator ( $\operatorname{Cos} \varnothing)$ dari 0,8 menjadi 0,65 . Hal ini jelas sangat merugikan jika ditinjau dari operasional sistem kerja pembangkit yang pada akhirnya akan menimbulkan kerugian bagi PKS (perusahaan).

Perhitungan Kapasitas Kapasitor Bank yang dipasang sesuai pada data.

Perbaikan yang diinginkan 0,85 maka :

$\mathrm{PF}$ awal $\operatorname{Cos} \varphi_{1}=0,65 \tan \varphi_{1}=1,169$

PF yang inginkan $\operatorname{Cos} \varphi_{2}=0.85$

$$
\tan \varphi_{2}=0.619
$$

Sehingga daya reaktif (kapasitor bank) yang diperlukan adalah:

$$
\begin{aligned}
Q_{\text {cap }} & =P\left(\tan \varphi_{1}-\tan \varphi_{2}\right) \\
& =300 \times 1000(1,169-0,619) \\
& =300 \times 1000(0,55) \\
& =300 \times 550 \\
& =165 \mathrm{kVar}
\end{aligned}
$$

Perhitungan kapasitor hubungan bintang :

$$
\mathrm{V} \text { cap }=\frac{\mathrm{VL}-\mathrm{L}}{\sqrt{\mathrm{a}}}=\frac{\mathrm{agO}}{\sqrt{\mathrm{a}}}=220 \text { volt }
$$

Kapasitas kapasitor adalah :

$$
\begin{aligned}
& \mathrm{C}_{\text {bintang }}=\frac{Q c}{(V L-L)^{2} x \omega}=\frac{Q c}{(V L-L)^{2} x 2 \mathrm{~m} x f} \\
& \mathrm{C}_{\text {bintang }}=\frac{165 x 1000}{(\operatorname{ag0})^{2} \times 2 \min x}=3,639 \mu F / F a s a
\end{aligned}
$$

Kapasitor Total :
$\mathrm{C}_{\text {Total }}=3 \times 3,639 \mu \mathrm{F}=10.917 \mu \mathrm{F}$

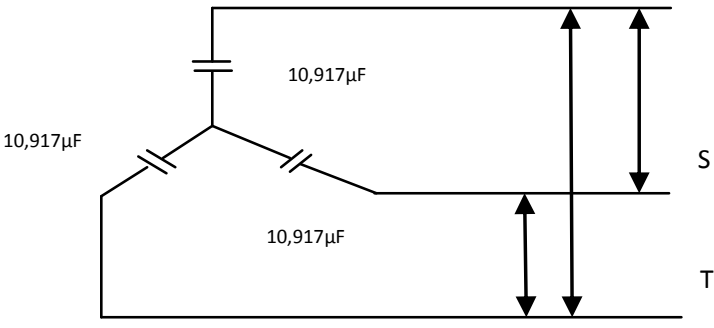

Gambar. 9 Kapasitor Hubung Bintang

Perhitungan Kapasitor Hubung Segitiga

Untuk hubung delta adalah :

$\mathrm{V}$ cap $=\frac{V L-L}{\sqrt{\sqrt{a}}}=\frac{a g 0}{\sqrt{1}}=220$ volt

Kapasitas Kapasitor adalah :

$$
\begin{gathered}
C_{\text {delta }}=\frac{Q c}{a x(V L-L)^{2} X \omega}=\frac{Q c}{a x(V L-L)^{2} x 2 \pi x f} \\
C_{\text {delta }}=\frac{165 x 1000}{a x(380)^{2} x 2 \pi x 50}=1,213 \mu F / F a s a
\end{gathered}
$$

Kapasitas Total :

$$
\mathrm{C}_{\text {Total }}=3 \times 1,213=3,693 \mu \mathrm{F}
$$

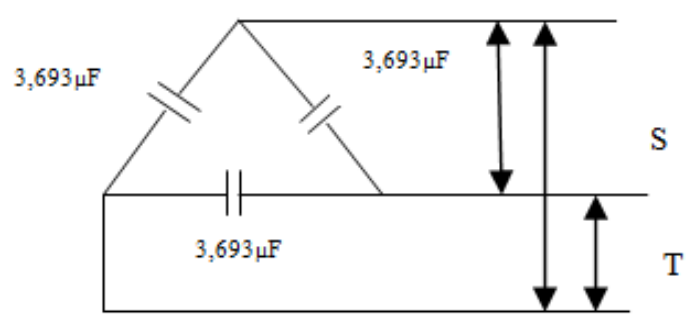

Gambar. 10 Kapasitor Hubung Delta

Power Factor (PF) Regulator

Power Factor (PF) Regulatormerupakan peralatan yang berfungsi untuk mengatur kompensasi kapasitor agar daya reaktif yang akan disupply ke jaringan atau sistem dapat bekerja sesuai kapasitas yang dibutuhkan. Acuan pembacaan besaran arus dan tegangan pada sisi utama maka daya reaktif yang dibutuhkan dapat terbaca dan regulator inilah yang akan mengatur kapan dan berapa daya reaktif 
yang diperlukan. Peralatan ini mempunyai bermacam macam step dari 6 step, 12 step sampai 18 step.

Bertambahnya beban yang mengandung beban induktif antara lain lampu mercury, motor-motor listrik, AC, maka dalam modul akan mendeteksi Kva menjadi lebih besar maka step-step kontaktor yang diaktifkan regulator akan masuk memberikan masukan daya reaktif yang dibutuhkan. Sebaliknya, apabila beban berkurang maka nilai VAR yang di suplai kapasitor menjadi berlebihan, hal ini akan dideteksi oleh regulator dan segera mengurangi pasokan kapasitor sehingga power factor menjadi seimbang kembali. Peralatan tambahan yang biasa digunakan pada panel kapasitor antara lain :

1. Selektor auto - off - manual yang berfungsi memilih sistem operasional auto dari regulator atau manual dari push button.

2. Push button on dan Push button off yang berfungsi mengoperasikan magnetic contactor secara manual.

\section{SIMPULAN}

Power Factor (Faktor Daya) yang juga selalu ditulis sebagai $\cos \emptyset$, merupakan bagian yang cukup penting dalam pengoperasian suatu Generator Listrik. Menurunnya faktor daya $(\cos \varnothing)$ akan berakibat turunnya efisiensi pembangkit dalam menampung beban kerja serta akan memperbesar kemungkinan terjadinya kerusakan pada sistem pembangkit. Generator dapat bekerja optimal jika semua persyaratan parameter kerjanya terpenuhi. Power Loss (keborosan Daya) yang diakibatkan turunnya Faktor Daya Generator ( $\operatorname{Cos} \varnothing)$ dari 0,8 menjadi 0,65. Hal ini jelas sangat merugikan jika ditinjau dari operasional sistem kerja pembangkit yang pada akhirnya akan menimbulkan kerugian akibat daya yang hilang mencapai 23\% dan kVAR naik 35,71\%.

Kapasitas Kapasitor yang dihubungkan Bintang dan delta dibutuhkan sebesar $15.897 \mu \mathrm{F}$ dan 5,292 $\mu F$. Kerugian daya juga menyebabkan arus listrik (I) yang mengalir melalui normalnya 456 A menjadi 561 A sehingga kabel hantaran menjadi bertambah besar sehingga ukuran kabel yang dibutuhkan juga bertambah besar. Hal ini akan menyebabkan bertambahnya biaya investasi pemasangan jaringan kabel

\section{DAFTAR PUSTAKA}

PUIL 200

Kadir, A., Distribusi dan Utilisasi Tenaga Listrik, Jakarta : UI - Press, 2000.

Sumardjati, P., Instalasi Motor, Bandung : POLBAN, 2000.

Tinus, A., Studi Pengaruh Capasitor Bank Switching Terhadap Kualitas Daya Listrik Di Gardu Induk Waru PLN P3B, Surabaya

Zuhal, Dasar Tenaga Listrik, Penerbit ITB Bandung, 1986.

B.L. Theraja, A Text-Book Of Technology,Nirja

Construction \& Development Co.Ltd.

Ir. Sulasno, Sistem Distribusi TenagaLsitrik, Badan Penerbit Universitas Diponegoro, Semarang, 2001.

Gonen, Thuran, Electric PowerDistribution System Engineering,McGraw-Hill Book Company, New Delh, 1986.

Blomquist, W.C., Capasitor for Industry, John Wiley \& Son Inc., New York, 1950

Longland T, TW Hunt \& Brecknell, Power Capasitor Handbook, Butterworth \& Co,1984.

Timothy J.E. Miller, Reactive PowerControl In Electric Systems, John Willey\& Sons, Inc, New York, 1982.

ESTAmat MH Mounting Instructions, Vishay Electronic GMBH.

Edminister, Joshep A, Rangkaian ListrikEdisi II, Erlangga, Jakarta, 1988.

[16]Hayt, W.H., J.E. Kemmerly. 1993, Rangkaian Listrik 1,Erlangga. Jakarta.

www. Indo.net.id/pln www.plnjaya.co.id/pelayanan 